under consideration by the Mental Health Act Commission.

LEONARD TARLO

Central Hospital,

Hatton,

Warwick CV35 7EE

\section{Hours of work}

The recent Department of Health and Social Security circular on junior doctors' working hours and the safety net review has been interpreted in this region as meaning that by 1 August 1993 al junior rotas should be reduced to one in four with prospective cover.

This department is staffed by two consultants and a senior registrar who work a one in three rota, with all three doing the same work while on cal except that the senior registrar is always covered by a consultant (when the senior registrar is attached to other departments, which is a requirement of his training, the consultants work a one in two rota) As from 1993 it seems that the senior registrar will not be allowed to be on call more than one in four, leaving the consultants to be on call three in eight with an additional one in eight to cover the senior registrar.

I have no objection to junior staff being given more time to enjoy life outside medicine, but if it is wrong for junior doctors on a short contract to work more than a one in four rota it puzzles me how it is right for a consultant, in addition to being continuously available to his own patients, to be on call three in eight or one in two for 30 years.

H R GULY

Accident and Emergency Department,

Derriford Hospital,

Plymouth PL6 8DH

** The secretary writes: "The circular is not as inflexible as has been suggested. It requires district working parties to make recommendations designed to reduce juniors' rotas, particularly those more onerous than one in three, recognising that in some cases this would not be possible within existing structures. There is no question of an outright prohibition on more onerous rotas, and in particular the district working parties have to take into account the requirement for a 'safety net' of intermediate level cover in the acute specialties. The Central Committee for Hospital Medical Services shares Dr Guly's concern about the position of consultants, which is why the chairman of the committee recently wrote to the Secretary of State to protest about the government's apparent failure to achieve its targets for consultant expansion (22 October, p 1051)."-ED, BMF.

\section{Longevity in Palau}

The longevity of the inhabitants of Palau (3 September, p 632) was attributed to the local traditional diet, with little alcohol, sugar, salt, and tobacco. I visited Palau last year and found to my dismay that young Palauans are trying their hardest to rectify this situation.

Budweiser beer is now the second largest import, ' and, indeed, it is extremely uncommon to see anybody in Palau aged under 50 who has not got a beer can in his hand and a cigarette in his mouth. They have also tackled the problem of traditional diet by ensuring that the island's few supermarkets are kept stocked with imported processed foods; in fact it is difficult to purchase local produce, although the Palauan Islands are exceedingly beautiful and contain one of the richest assortments of marine life associated with coral reefs anywhere to be found on this planet. If you order fish in a restaurant it is more likely than not fresh from a can.

The Palauans have also ensured that they have little cause to exert themselves: almost everybody has a car, there is no public transport system, and the main road through Koror is always very busy with traffic despite the fact that the island is no more than three miles long. It will be interesting to see whether the modernisation of Palau has any beneficial effect on that nation's health.

PAUL HEATON

Southland Area Health Board,

Southland Hospital,

Invercargill,

New Zealand

1 Patterson CB. In the far Pacific: at the birth of nations. National Geographic 1986;170:460-99.

\section{Points}

\section{Moslems and consent}

Professor Kandil SHAKER (Centre for Educational Development for Health Personnel, University of Jordan, Amman, Jordan) writes: Minerva quotes from an article in Injury about consent by the Afghani mujahadeen and implies that Islamic practices discourage surgical or medical treatment (17 September, p 748). On the contrary, Islam stipulates that each Moslem in need of medical or surgical care should seek and accept such care as part of being a good Moslem. Any Moslem who does not seek or refuses medical help is considered by all Sharia doctrines to be disobedient and may not enter heaven until he repents. If a patient's consent for treatment is sometimes difficult to obtain in Afghanistan, this is probably because of difficult war conditions or tribal cultural traditions, which have nothing to do with the merciful spirit of Islam.

\section{The closed eye sign}

Dr H G EASTON (Oban PA37 1SR) writes: Dr Derek W R Gray and others (1 October, p 837) state that patients with non-specific abdominal pain who show "the closed eye sign" often have an expression inappropriate to a patient with pain. Earlier it was put thus: "Typically the eyelids are held exquisitely closed and the face wears an embalmed beatific smile." That description tallies with "belle indifférence," a feature typical of hysteria. ${ }^{2}$ It is important not to overlook the diagnosis of hysteria; otherwise an essentially curable clinical state may result in prolonged illness with an endless search for obscure somatic disease. ${ }^{3}$

1 Gray DW, Collin J. The closed eye sign. Br Med f 1987;295: 1656.

2 Janet PMF. The major symptoms of hysteria, 1907. Cited in: Henderson DK, Gillespie RD. A textbook of psychiatry. 4th ed. London: Oxford University Press, 1936:446, 594.

3 Walshe FMR. The diagnosis of hysteria. Br Med $\mathcal{J}$ 1965;ii: $1451-4$

Dr Elizabeth M RoBERTSON (Department of Diagnostic Radiology, Aberdeen Royal Infirmary, Aberdeen AB9 2ZB) writes: In performing ultrasonic investigations I have observed that certain groups of patients with abdominal pain do shut their eyes during the examination or part of it. I have not made any serious attempt to correlate this with the ultrasonic findings, but this may be an area in which it is possible to extrapolate the findings of Dr Derek W R Gray and others.

\section{Drugs in Australia}

Mr W Coote (Australian Medical Association, Glebe, NSW, Australia) writes: Minerva suggests that recent changes to the Australian Pharmaceutical Benefits Scheme mean that new expensive drugs, such as angiotensin converting enzyme inhibitors, are not available under the scheme and that patients must pay for them themselves (24 September, p 802). Fifty three drugs, including angiotensin converting enzyme inhibitors, have been added to a list for which written authority is needed before the government will subsidise their cost; this requires doctors to fill in a complicated form. The Australian Medical
Association has vigorously opposed the changes because of threats to autonomy and doctor-patient confidentiality. In most cases the form requires unnecessary disclosure of the patient's condition and for many drugs the doctor also has to say that there is no cheaper alternative drug. It is not, however, true to say that the drugs are not available under the scheme.

\section{Preoperative biochemical screening}

Drs K A Milligan and P McHugh (Department of Anaesthesia, Medical School, Sheffield S10 2RX) write: Drs Iain T Campbell and Peter Gosling (1 October, p 803) remind us that many biochemical investigations are superfluous to normal requirements. ${ }^{14}$ Unfortunately, they go on to advise that simple urine testing is adequate for patients aged under 50; but this method is not foolproof,' and it may easily be performed badly and misinterpreted. Surely it would be of greater value for each hospital to issue guidelines to its junior staff about routine biochemistry. These guidelines could be drawn up by the departments of surgery, anaesthesia, and biochemistry' and would provide a more rational basis for routine investigations and ensure that those patients in need of preoperative investigations are not neglected. This system might also improve the knowledge and awareness of the inexperienced junior staff referred to in the editorial.

1 Blery C, Charpak Y, Szatan M, et al. Evaluation of a protocol for selective ordering of pre-operative tests. Lancet 1986;1:139-41. 2 Kaplan EB, Scheiner LB, Boeckmann AJ, et al. The usefulness of preoperative laboratory screening. $\mathcal{F} A M A$ 1985;153:3576-81. McKee RF, Scott EM. The value of routine preoperative investigations. Ann R Coll Surg Engl 1987;69:160-2.

Catchlove BR, Wilson RM, Spring S, Hall J. Routine investigations in elective surgical patients. Med f Aust 1979;ii:107-10. Zilva JF. Is unselective biochemical urine testing cost effective? BrMed f 1985;291:323-5.

\section{Antibiotics in emergency bags}

Dr D Hall (Pinhoe, Exeter EX1 3RF) writes: Might I suggest one reason for the finding of Drs Edmund L C Ong and Edward M Dunbar that not all general practitioners carry parenteral penicillin for meningococcal infection (8 October, p 901)? I started recently as a trainee and ordered parenteral penicillin for just such a clinical situation but was dismayed to find that the pharmacy could order only a minimum of 100 ampoules. A general practitioner would therefore have to order hundreds of ampoules in his or her lifetime with only a slim chance of using them. I am sure it would be beneficial if pharmaceutical firms could prepare smaller packs of, say, five ampoules.

\section{Referrals to hospital}

Dr I St J KEM (Battle, East Sussex TN33 9JL) writes: Drs F P Howarth and Jan Maitland suggest that the workload referral rate would be a better measure of referral from general practice (1 October, $p$ 856). But merely adding up the numbers of referrals is not very helpful because it lumps together those made because the general practitioner is uncertain about diagnosis and treatment and those made because he or she knows that particular conditions should be referred. For example, since having worked as a clinical assistant in dermatology I refer more cases to the consultan because I recognise their importance. There are also referrals over which the general practitioner has no control, such as those prompted by opticians and child health clinics, and these cannot reflect the genera practitioner's competence.

\section{Correction}

\section{Consensus on cancer therapy}

An error occurred in this letter by Mr D Newling ( 8 October, p 919). A second consensus conference on prostatic cancer accompanied by the first consensu conference on testicular cancer will take place in Hull on 12-15 April 1989, not on 12-15 May as published. Further details are available from Miss Pat Hodgins, Yorkshire Regional Cancer Organisation, Cookridge Hospital, Leeds LS16 6QB. 